\title{
The Exploration and Practice of the Model of Training Skilled Application of Electronic Technology Professional Technical Talents
}

\author{
Guocan Ren, Sufang Yuan \\ Ningbo City College of Vocational Technology, Zhejiang Province, China \\ renguocan@nbcc.cn, yuansufang@nbcc.cn
}

\begin{abstract}
Higher vocational colleges must successfully realize the goal of training technical talents, must have a reasonable training plan for support. This paper starts with the connotation of talents training mode and characteristics, analyzes the elements of talents training mode, the mode of goal system and content system construction of cultivating talents of applied electronic technology specialty, in order to promote the adjustment and construction of professional guidance, setting, teaching content and teaching method reform of curriculum, and the construction of personnel training mode the exploration and practice of effective.

Index Terms - technology, skill, training mode, application of electronic technology
\end{abstract}

\section{Introduction}

In recent years, our country's higher vocational education gets rapid development, has become an important type of China's higher education, higher vocational colleges has become the main technology in our country skilled talents cultivating base.

With the development of our country's economy, increasing demand for talents, higher vocational education ushered in the great development opportunities, also faces serious challenges. In vocational colleges through the application of electronic technology professional training mode of exploration and practice, put forward the technology skilled talents of the personnel training mode.

Structure mode can be divided into three levels to carry out the construction of talent cultivation of Applied Electronic Technology specialty. The first level is the goal system of talents cultivation, mainly refers to the training objectives and specifications of professional; the second level is the content system of personnel training, mainly refers to the teaching content, teaching method and means, the training way; the third level is the guarantee of talents cultivation system, mainly refers to teachers, practice base, teaching management and teaching evaluation etc.

\section{The Meaning of Training Mode of Technical Skills Talents and Characteristics}

\section{A. The meaning of training mode of technical skills talents}

Technical skills talents, is a profound professional knowledge, application technology to master modern high level, have skilled operational skills, and can work in practice enough high-quality talent solve operational problems and process technology independence.

\section{B. Patterns of technical skills talents cultivation}

Teach high [2006] no. 16 on 《the comprehensive several opinions on improving the quality of higher vocational education teaching $》[1]$, has clearly put forward in the higher vocational education as a type of higher education development, personnel training mode has its own distinct characteristics. Teach high [2000] no. 2 of 《the ministry of education on strengthening vocational education personnel training work opinion》[2]also explicitly pointed out that in the basic features of higher vocational education personnel training mode is: training to adapt to production, construction, management and service first line need higher technology applied talents as a fundamental task; To adapt to the social demand as the goal, train technology application ability as the main line design students' knowledge, ability and quality structure and cultivation scheme.

\section{The Structure System of Training Mode of Technical Skills Talents}

Technology skilled talents training mode is mainly around "culture technology skilled high-quality talents" and "how to train skilled qualified talent" of these two fundamental issues. Therefore, we will structure system in three aspects of cultivating talents for building. The first level is the goal of talent cultivation system, mainly refers to the professional training objectives and specifications; The second level is the contents of the personnel training system, mainly refers to the teaching contents, teaching methods and means, training methods, etc.; The third level is the guarantee of talents cultivation system, mainly refers to the teaching staff, teaching practice base, teaching management and teaching evaluation, etc[3].

\section{The Construction of Training Mode of Skilled Application of Electronic Technology Professional Technical Talents}

\section{A. Construction of the target system}

The goal system of talents training mode from the training aim and specifications. Training goal is mainly to solve the problem of high skilled personnel training direction, while the training is mainly to solve the quality problems of talent training, is a concrete manifestation of training objectives. Personnel training goal only refine training specifications for talent, to the specific implementation, in order to carry out the whole process of personnel training[4]. 


\section{1) Clear training objectives}

The cultivation of high skilled talents with high quality has become the most important task of the higher vocational college, talents is very clear. According to the specific characteristics and the development of industry of our country economy, training aim of applied electronic technology specialty is: to cultivate a good occupation morality and spirit of dedication, with the electronic technology basic knowledge of thick, master the technical skills of high quality applied talents of related professional skills.

\section{2) Accurate localization of the training specifications}

The essential characteristics of technology talents is a profound professional knowledge and application skills of high level, have skilled operational skills, able to solve problems independently operating technology and in practical work. That is practical and practical distinct their occupation characteristics, with a high level of clarity. Training of applied electronic technology specialty is mainly embodied in the knowledge, ability and quality etc.

\section{$B$. The construction of content system}

From the analysis of professional construction angle, training content system model includes professional setting, curriculum system, teaching content, teaching methods and means, training etc.

\section{1) According to the social needs of professional settings}

Higher vocational colleges must follow "to the employment as the guidance, based on professional post" to the principle of comprehensive study of professional Settings.

\section{2) To construct a scientific curriculum system}

To implement technology skilled high-quality talent training goal, we must build up the scientific benefit the course system of talent training, this is the core part. Curriculum system design for led by professional construction committee, invite related industries, enterprises, institutions of higher learning, education department related personnel to participate in, according to the economic and social demand for talents determine the curriculum system.

\section{3) Select the teaching content}

Technology skilled talents training mode of theory and practice of teaching should coexist, and more practice. According to the knowledge, ability and quality in the process of personnel training requirements set theory and the practice teaching system and content.

\section{4) Teaching method and teaching means}

Application of electronic technology, as a professional in the process of talent cultivation for engineering, should be in real or simulated environment to strengthen the training of students' vocational skills, exert students' main body participation, raises student's innovation ability.

Teaching method can be a lot on using simulation technology, virtual technology, computer network and other modern teaching means, build form a complete set of practice teaching and course teaching.
5) Through the cooperation between school and enterprise implementation ways of training

Higher vocational education personnel training mode reform is the focus of the teaching process of practicality, openness and occupational, should attach great importance to the consistency of school students and the actual work. Therefore, the application of electronic technology professional must combine engineering as an important point of the higher vocational education personnel training mode reform.

\section{The construction of social security system}

\section{1) The construction of double qualified teaching team}

In order to ensure the implementation of high skilled personnel training, we must strengthen the construction of teaching team, especially the construction of high-quality double qualified teaching team.

(1) multi channel construction double qualified teaching team

Double structure for the construction of teaching team, the first to fully tap potential in the school, in addition to the professional full-time teachers pageant has double quality of faculty and corporate experts enrichment in the professional teachers.

\section{(2) to strengthen the training of Teachers}

Professional double structure of the teaching team construction should stick to the guideline of "paying equal attention to introduction and training". For teachers, constantly improve the level of theory at the same time, should be planed and orderly way to let them to the production, construction, management, service the first line or school exercise close cooperative enterprises, improve their teaching skills. Must strengthen the training of their theory at the same time, efforts to improve their academic level and theoretical level[5].

2) Construction of school practice teaching base of high quality

Practice teaching base construction is the hardware implementation technology skilled talents cultivating. Professional should stick to the principle of high starting point, high quality, high standard requirements stated in the course teaching campus practice teaching base construction. At the same time, must be planned and systematic construction of a batch of off-campus practice teaching base, cultivate students engaged in and do a professional group, solve practical problems in the production practice and engineering projects of technology and management ability.

In short, the application of electronic technology professional, high quality construction of high-skilled personnel training mode, aimed at to scientific thinking and scientific operating method to realize the scale of the training of skilled talents, and the construction of this model should be from the target system, content system and guarantee system and so on several aspects, all levels should play a role of their own, and reflect their respective functions, and coordination, to achieve the high quality, the overall objective of highskilled personnel training, organization, implementation in place, only three levels of talent training mode can obtain the 
complete build, high quality and high skill talented person's raise to be secure.

\section{References}

[1] (2006) No. 16 high "about improving the quality of teaching in the higher occupation education of a number of opinions".

[2] Taught high [2000]2 "Ministry of education to strengthen higher vocational education personnel training work opinions".
[3] He Xiuyan, "mode for training high skilled talents in higher vocational colleges", research of higher engineering education, 2009 third.

[4] Qian Yonglin, "the higher vocational electrical manipulation wood professional talent training mode study", Chinese power education, 2 a 3, 2004.

[5] Qi Xiaohong, "Vocational "Double Teachers team building", "of Inner", Mongolia Radio \& TV University, 2008 fourth. 